\title{
Systemic Resistance Induced by Trichoderma spp.: Interactions Between the Host, the Pathogen, the Biocontrol Agent, and Soil Organic Matter Quality
}

\author{
H. A. J. Hoitink, L. V. Madden, and A. E. Dorrance
}

Department of Plant Pathology, The Ohio State University/OARDC, Wooster 44691.

Accepted for publication 19 June 2005.

\begin{abstract}
Hoitink, H. A. J., Madden, L. V., and Dorrance, A. E. 2006. Systemic resistance induced by Trichoderma spp.: Interactions between the host, the pathogen, the biocontrol agent, and soil organic matter quality. Phytopathology 96:186-189.

Several factors affect the ability of Trichoderma spp. to provide systemic disease control. This paper focuses on the role of the substrate in which plants are grown, resistance of the host to disease, and the ability of introduced Trichoderma inoculum to spread under commercial conditions. Several reports reveal that foliar disease control provided by Trichoderma spp. is more effective on plants grown in compost-amended media compared with in lower-in-microbial-carrying-capacity sphagnum peat media. In Rhododendron spp., host resistance affects control of Phytophthora dieback provided by Trichoderma spp. For example, T. hamatum 382 (T382) significantly $(P=0.05)$ suppressed the disease on
\end{abstract}

ABSTRACT susceptible cv. Roseum Elegans while plant vigor was increased. The disease was not suppressed, however, on highly susceptible cvs. Aglo and PJM Elite even though the vigor of these plants was increased. Using a strain-specific polymerase chain reaction assay under commercial conditions, it was demonstrated that introduced inoculum of T382 did not spread frequently from inoculated to control compost-amended media. Other Trichoderma isolates typically are abundant in control media within days after potting unless inoculated with a specific Trichoderma isolate. Thus, the low population of isolates that can induce systemic resistance in composting and potting mix environments may explain why most compost-amended substrates do not naturally suppress foliar diseases.

Additional keywords: biological control, Botryosphaeria dothidea, Myrica pennsylvanica, Phytophthora citricola, Phytophthora citrophthora, Phytophthora parasitica.
Composts applied to soils frequently have been shown to suppress the severity of diseases caused by soilborne plant pathogens, particularly those caused by Pythium and Phytophthora spp. (4,7, 12,33). The degree of suppression obtained varies and several factors contribute to efficacy. An in depth review of this topic for field soils was published recently (31). Composts have been used successfully for container-produced plants, the focus of this paper, particularly when inoculated with specific biocontrol agents $(5,12)$. Even foliar diseases can be affected by such inoculants although composts typically do not provide this systemic effect naturally $(18,25)$.

Early during the development of container media, it was learned that peat mixes generally do not suppress Pythium or Phytophthora root rots. Even if they are suppressed initially in peat mixes, the effect is short term in nature (3). Fungicides such as metalaxyl that can effectively control these root rots were not available until the mid-1970s. Phytophthora root rot therefore posed serious problems in this industry. During the 1950s, U.S. and Australian nurseries introduced bark from several different tree species as peat substitutes into container media. It was observed that "aged" or composted bark-amended media seemed to naturally suppress Phytophthora and Pythium root rots. Several reports have substantiated these observations $(2,8,9,14,17,21,29)$.

Corresponding author: H. A. J. Hoitink; E-mail address: hoitink.1 @ osu.edu

DOI: 10.1094/PHYTO-96-0186

(C) 2006 The American Phytopathological Society
Almost immediately after suppressive media became available, nurseries increased fertility inputs to shorten production cycles because Phytophthora root rot no longer posed a threat. The net result was increased susceptibility of crops such as Rhododendrons to Phytophthora spp. that cause shoot blight and dieback (15). Thus, although free of root rot, susceptible crops still had to be sprayed on the foliage with fungicides, particularly in humid climates or where overhead irrigation was used so that leaf wetness periods were long enough to allow infections to develop.

Specific microbial inoculants. Compost-amended media typically suppress Pythium and Phytophthora root rots within days after their formulation $(5,12)$. Even so, only a small percentage of such media suppress Rhizoctonia damping-off $(19,20,32)$. An even smaller percentage of composts provides control of foliar diseases, presumably by inducing systemic resistance to disease in plants (18). Inoculation of such media with specific biocontrol agents has provided more predictable control of all three types of diseases $(18-20,24,25)$.

Systemic effects induced by composts in plants against diseases are expressed more consistently in the roots than in the foliage of plants (35,36). Trichoderma hamatum 382 (T382) was identified as providing the most significant degree of control of foliar disease from among $>500$ rhizosphere microorganisms isolated from 2 of 80 different batches of composts which naturally suppressed foliar diseases $(10,18)$. Isolates of several other Trichoderma spp. have been described that can reduce the severity of foliar diseases, presumably by inducing systemic resistance in plants $(6,22$, 30,34). Populations of $T$. hamatum and T. harzianum often are abundant in composts $(12,23)$. Thus, Trichoderma spp. should be 
a good candidate for inoculation of composts to provide control of foliar diseases more consistently.

The mechanisms by which beneficial rhizosphere microorganisms induce systemic resistance in plants differ $(11,26)$. It is not known how Trichoderma isolates induce this effect in plants (11). Some isolates activate pathogenesis-related protein synthesis before the pathogen invades the host plant (11), whereas others such as T. hamatum 382 (T382) do not have this effect (36). Even so, the population of the pathogen as well as the severity of the disease can be reduced by any of several Trichoderma isolates $(10,11,17,18,36)$.

Role of the substrate in induced resistance. Several reports show that potting mixes prepared with sphagnum peat do not induce systemic resistance in plants $(17,18,25,36)$. Although inoculation of peat mixes with some biocontrol agents can lead to systemic resistance, amendment of such media with composts increases efficacy. For example, Fusarium crown and root rot of tomato induced by the biocontrol agent Pythium oligandrum is enhanced by amending a sphagnum peat mix with compost (25). Similarly, suppression of Phytophthora crown and root rot and of leaf blight induced by T382 in cucumber against Phytophthora capsici is more consistent in a peat mix if amended with composted dairy manure (17). Furthermore, powdery mildew and Botrytis blight of begonia have been suppressed more effectively by T382 in a compost-amended mix than in the control sphagnum peat mix (16).

The degree of protection provided by isolates of Trichoderma spp. that induce systemic resistance in plants can be as effective as that provided by fungicides. For example, the degree of control provided by T382 against Phytophthora capsici in cucumber was as effective as that provided by a drench with metalaxyl (17). Furthermore, control of powdery mildew and Botrytis blight of begonia was as effective as that provided by topical sprays with piperon and chlorothalonil, respectively (16). The foregoing suggests that the degree of systemic disease control that can be provided by Trichoderma isolates should be good enough to be of interest to growers. Since laboratory studies have shown that composts used widely by the nursery industry seem to enhance the level of resistance induced and because such natural field-scale produced composts typically do not provide this effect, opportunities are excellent for improving efficacy through the introduction of controlled inoculants. The following section provides information on the spectrum of diseases that have been reduced in severity in nurseries by this novel approach to control foliar diseases with composts.

Efficacy of Trichoderma-fortified composts in nurseries. To determine the practical significance of the suppressive effect provided by systemic induced resistance under commercial condi-

TABLE 1. Suppression of Botryosphaeria dieback on Myrica pennsylvanica induced by Trichoderma hamatum 382 (T382) in a compost-amended container medium

\begin{tabular}{lccc}
\hline $\begin{array}{l}\text { Container } \\
\text { medium }^{\mathrm{a}}\end{array}$ & $\begin{array}{c}\text { Median dieback } \\
\text { severity }^{\mathrm{b}}\end{array}$ & $\begin{array}{c}\text { Mean plants } \\
\text { killed }(\%)^{\mathrm{b}}\end{array}$ & $\begin{array}{c}\text { Mean symptomless } \\
\text { plants }(\%)\end{array}$ \\
\hline Control & 2.4 & 20.8 & 25.0 \\
T382 & $1.5^{* \mathrm{c}}$ & $6.3^{*}$ & $66.7^{*}$ \\
\hline
\end{tabular}

a Control container medium and the same but inoculated with T382 (120 g of dry granular inoculum $\mathrm{m}^{-3}$ medium).

${ }^{\mathrm{b}}$ Dieback severity rating based on four blocks of 12 plants per treatment determined on 16 May 2002, using a scale in which $1=$ symptomless and $4=$ dead plant. Plants were considered as subsamples within each block and treatment. Severity rating was analyzed with a nonparametric analysis based on ranks, as described in Shah and Madden (28). Percentages were analyzed with analysis of variance, after first transforming the data with the angular transformation; means were back-transformed to percentages for presentation purposes.

c * Indicates that the mean for T382 was significantly $(P=0.05)$ different from the mean for the control, based on an $F$ test of a contrast of the means of transformed percentages or means of the ranks. tions, demonstration trials were performed in nurseries with T382 in a widely used container medium (13). It was prepared from the following ingredients: 65\% aged (composted) pine bark (all particles $<20 \mathrm{~mm}$ diameter), $15 \%$ light fibrous sphagnum peat, $10 \%$ composted municipal sewage sludge, $7 \%$ expanded shale, and $3 \%$ sharp silica sand, all on a volume basis. Chemical additives were dolomitic lime stone $\left(2 \mathrm{~kg} \mathrm{~m}^{-3}\right)$, gypsum $\left(1 \mathrm{~kg} \mathrm{~m}^{-3}\right)$, and slow release fertilizer at the recommended rates for the crops used. The temperature of both composts was $>50^{\circ} \mathrm{C}$. The container medium was inoculated during its formulation with T382 by adding $120 \mathrm{~g}$ of a granular preparation of T. hamatum 382 produced by Sylvan Bioproducts, Inc. (West Hills Industrial Park, Kittanning, PA) per cubic meter of potting medium. The mixture was blended for $3 \mathrm{~min}$ in a mixer and water was added to adjust its total water content to within the range of 50 to $55 \%$. Addition of water also decreased the temperature of the mix to $<35^{\circ} \mathrm{C}$ so that the introduced inoculum could survive and colonize the substrate before wild-type Trichoderma isolates colonized this niche. The control medium was not inoculated with T382. The population of T382 in the media was monitored by dilution plating on a Trichodermaselective medium, as described in Khan et al. (17). The identity of presumptive isolates of T382 was verified with a polymerase chain reaction (PCR) assay (1).

In one case study in a nursery, rooted cuttings of Myrica pennsylvanica that had become infected with Botryosphaeria dothidea during propagation were repotted into the control container medium but inoculated with T382. A Botryosphaeria leaf blight and stem dieback epidemic developed naturally after potting while the crop broke dormancy and produced new growth (13). A high percentage $(21 \%)$ of plants in the control medium were killed by the disease and only $25 \%$ remained symptomless (Table 1$)$. In contrast, $6 \%$ of the plants in the T382-inoculated medium were killed, whereas $67 \%$ of the plants remained symptomless. Thus, inoculation of the container medium with T382 significantly $(P=$ 0.05) suppressed the severity of Botryosphaeria dieback.

In another case study in a nursery, but with rooted cuttings of Rhododendron catawbiense cv. Roseum Elegans, a natural Phytophthora dieback epidemic developed (13). The pathogens that caused the epidemic were identified as Phytophthora citrophthora and Phytophthora citricola, based on morphological characteristics and internal transcribed spacer sequence (27). The area under the disease progress curve, based on the number of plants with symptoms over time, revealed that the introduced Trichoderma inoculum significantly $(P=0.05)$ reduced the incidence of Phytophthora dieback under very high disease pressures (Table 2). In another case study with the Rhododendron cvs. Aglo and PJM Elite, Phytophthora parasitica caused a severe Phytophthora leaf blight and stem dieback epidemic. Most plants of both culti-

TABLE 2. Suppression of Phytophthora shoot blight and dieback on Rhododendron cv. Roseum Elegans induced by Trichoderma hamatum 382 (T382) in a compost-amended container medium

\begin{tabular}{lcl}
\hline & \multicolumn{2}{c}{ Disease incidence } \\
\cline { 2 - 3 } Treatment $^{\mathrm{a}}$ & $\%$ Plants killed $^{\mathrm{b}}$ & AUDPC $^{\mathrm{b}}$ \\
\hline Control & 83.7 & 826.2 \\
T382 & $71.7^{* \mathrm{c}}$ & $701.8^{*}$ \\
\hline
\end{tabular}

a Control container medium and the same but inoculated with T382 (120 g of dry granular inoculum $\mathrm{m}^{-3}$ medium).

b Plants were potted in October 2002 and evaluated monthly for dieback symptoms during the 2003 and 2004 growing seasons. Disease incidence based on four replications of 120 plants per treatment, expressed as percentage of plants killed and area under disease progress curve (AUDPC). Plants were considered subsamples within replications. Percentages were first transformed with the angular transformation prior to analysis of variance; means were back-transformed to percentages for presentation purposes.

c * Indicates that the mean percentage for T382 was significantly $(P=0.05)$ different from the mean for the control based on an $F$ test of a contrast of the transformed means 
vars were killed and the introduced inoculum of T382 did not significantly affect the incidence of Phytophthora dieback. In spite of this, branching and the vigor of both crops were increased.

The Phytophthora diseases developed on all three Rhododendron cultivars even though they had been treated at recommended intervals with the Phytophthora fungicides metalaxyl (Subdue GR, Syngenta Crop Protection, Inc., Greensboro, NC) and aluminum tris (O-ethyl phosphonate) (Aliette WDG, Bayer Corp., Montvale, NJ). In vitro analysis revealed that the Phytophthora isolates that caused the epidemic were resistant to metalaxyl (100 $\mathrm{mg} \mathrm{ml}^{-1}$ ).

In each of the demonstration trials, the population of the introduced Trichoderma inoculum (T382) increased to 2 to $4 \times$ $10^{6} \mathrm{CFU} \mathrm{g}^{-1}$ dry weight container medium within 14 days after potting. It remained at that population thereafter. Other Trichoderma isolates typically were present at much lower populations $\left(<10^{5} \mathrm{CFU} \mathrm{\textrm {g } ^ { - 1 }}\right.$ substrate) in the fortified medium. The introduced isolate occasionally spread to the control medium in pots placed immediately adjacent inoculated media. In contrast, the total Trichoderma population recovered from the control medium ranged from 2 to $4 \times 10^{6} \mathrm{CFU} \mathrm{g}^{-1}$ dry weight medium, as described earlier for such substrates (23). The identity of presumptive T382 isolates was confirmed with the PCR assay. Thus, the introduced Trichoderma inoculum did not spread much under commercial conditions.

Implications for commercial applications. Suppression of Phytophthora dieback of Rhododendron cv. Roseum Elegans with T382 in the full-scale nursery trial verified the systemic effect induced by this biocontrol agent in Pieris japonica against Phytophthora dieback caused by Phytophthora parasitica (13) and by isolate T-203 of T. harzianum on pepper (30). It was not as effective as that reported for T382 on cucumber against $P$. capsici (17). On Pieris japonica, the percentage of plants killed by the disease was reduced from $24 \%$ in the control medium to $4 \%$ in the medium inoculated with T382 (13). Pieris japonica often recovers from dieback due to its resistance to Phytophthora relative to Rhododendron cv. Roseum Elegans. In contrast, lack of significant control induced by T382 in the Rhododendron cvs. Aglo and PJM Elite may be due to their extreme susceptibility to Phytophthora spp. The crown portion and roots of these plants rate among the most susceptible of more than 500 Rhododendron species and hybrids and tested for resistance against Phytophthora cinnamomi (14). Roseum Elegans, although also susceptible to root rot and dieback, is much more resistant than PJM Elite. It is possible, therefore, that the systemic effect induced by T382 cannot be activated in PJM Elite and like cultivars, presumably due to lack of resistance to the disease. This could limit application of systemic induced resistance in disease control on some nursery crops. Another factor that needs to be considered is $\mathrm{N}$ fertility which significantly affects Phytophthora dieback severity on Rhododendron spp. (15). Since introduced Trichoderma isolates may increase plant vigor (11), a level lower than the standard level of $\mathrm{N}$ fertility might suffice and this would decrease dieback severity (15).

The foregoing nursery tests revealed that inoculation of container media which naturally suppress Phytophthora root rots with some specific inoculants of Trichoderma spp. can induce systemic resistance in plants against aggressive foliar Phytophthora spp. The significance of these findings must be explored further. It would seem, however, that the suppressive effect observed against Botryosphaeria dieback may become a novel method of control for this stress disease. Fungicides that effectively control this severe disease of woody plants are not available to our knowledge. Because the introduced Trichoderma inoculum did not spread much naturally, it would seem that opportunities for utilization of this still rather novel approach to disease control should be bright.

\section{ACKNOWLEDGMENTS}

This work was supported by grants from The Ohio Water Development Authority, Columbus, OH, and by State and Federal Funds appropriated to The Ohio State University and The Ohio Agricultural Research and Development Center, Wooster, OH. Technical assistance by C. A. Musselman and T. L. Moore is acknowledged gratefully.

\section{LITERATURE CITED}

1. Abbasi, P. A., Miller, S. A., Meulia, T., Hoitink, H. A. J., and Kim, J. 1999. Precise detection and tracing of Trichoderma hamatum 382 in compost-amended potting mixes by using molecular markers. Appl. Environ. Microbiol. 65:5421-5426.

2. Aryantha, I. P., Cross, R., and Guest, D. I. 2000. Suppression of Phytophthora cinnamomi in potting mixes amended with uncomposted and composted animal manures. Phytopathology 90:775-782.

3. Boehm, M. J., Wu, T., Stone, A. G., Kraakman, B., Iannotti, D. A., Wilson, G. E., Madden, L. V., and Hoitink, H. A. J. 1997. Cross-polarized magic-angle spinning ${ }^{13} \mathrm{C}$ nuclear magnetic resonance spectroscopic characterization of soil organic matter relative to culturable bacterial species composition and sustained biological control of Pythium root rot. Appl. Environ. Microbiol. 63:162-168.

4. Craft, C. M., and Nelson, E. B. 1996. Microbial properties of composts that suppress damping-off and root rot of creeping bentgrass caused by Pythium graminicola. Appl. Environ. Microbiol. 62:1550-1557.

5. De Ceuster, T. J. J., and Hoitink, H. A. J. 1999. Prospects for composts and biocontrol agents as substitutes for methyl bromide in biological control of plant diseases. Compost Sci. Util. 7:6-15.

6. De Meyer, G., Bigirimana, J., Elad, Y., and Höfte, M. 1998. Induced systemic resistance in Trichoderma harzianum T39 biocontrol of Botrytis cinerea. Eur. J. Plant Pathol. 104:279-286.

7. Downer, A. J., Menge, J. A., and Pond, E. 2001. Association of cellulytic enzyme activities in eucalyptus mulches with biological control of Phytophthora cinnamomi. Phytopathology 91:847-855.

8. Erhart, E., and Burian, K. 1997. Evaluating quality and suppressiveness of Austrian biowaste composts. Compost Sci. Util. 5:15-24.

9. Fichtner, E. J., Benson, D. M., Diab, H. G., and Shew, H. D. 2004. Abiotic and biological suppression of Phytophthora parasitica in a horticultural medium containing composted swine waste. Phytopathology 94:780-788.

10. Han, D. Y., Coplin, D. L., Bauer, W. D., and Hoitink, H. A. J. 2000. A rapid bioassay for screening rhizosphere microorganisms for their ability to induce systemic resistance. Phytopathology 90:327-332.

11. Harman, G. E., Howell, C. R., Viterbo, A., Chet, I., and Lorito, M. 2004 Trichoderma species-opportunistic, avirulent plant symbionts. Nature Rev. Microbiol. 2:1-14.

12. Hoitink, H. A. J., and Boehm, M. J. 1999. Biocontrol within the context of soil microbial communities: A substrate-dependent phenomenon. Annu. Rev. Phytopathol. 37:427-446.

13. Hoitink, H. A. J., Musselman, C. A., Moore, T. R., Horst, L. E., Krause, C. R., Zondag, R. A., and Mathers, H. 2003. Biological suppression of foliar diseases of ornamental plants with composted manures, biosolids and Trichoderma hamatum 382. Pages 50-56 in: Ornamental Plants Special Circ. 189. Ohio Agricultural Research and Development Center, Wooster.

14. Hoitink, H. A. J., and Schmitthenner, A. F. 1974. Resistance of Rhododendron species and hybrids to Phytophthora root rot. Plant Dis. Rep. 58:650-653.

15. Hoitink, H. A. J., Watson, M. E., and Faber, W. R. 1986. Effect of nitrogen concentration in juvenile foliage of rhododendron on Phytophthora dieback severity. Plant Dis. 70:292-294.

16. Horst, L. E., Krause, C. R., Madden, L. V., and Hoitink, H. A. J. 2003. Suppression of powdery mildew and Botrytis blight of begonia induced by Trichoderma hamatum 382 in peat and compost-amended potting mixes. (Abstr.) Phytopathology 93(suppl.):S37.

17. Khan, J., Ooka, J. J., Miller, S. A., Madden, L. V., and Hoitink, H. A. J. 2004. Systemic resistance induced by Trichoderma hamatum 382 in cucumber against Phytophthora crown rot and leaf blight. Plant Dis. 88:280-286.

18. Krause, M. S., De Ceuster, T. J. J., Tiquia, S. M., Michel, F. C., Jr., Madden, L. V., and Hoitink, H. A. J. 2003. Isolation and characterization of rhizobacteria from composts that suppress the severity of bacterial leaf spot of radish. Phytopathology 93:1292-1300.

19. Krause, M. S., Madden, L. V., and Hoitink, H. A. J. 2001. Effect of potting mix microbial carrying capacity on biological control of Rhizoctonia damping-off of radish and Rhizoctonia crown and root rot of poinsettia. Phytopathology 91:1116-1123.

20. Kwok, O. C. H., Fahy, P. C., Hoitink, H. A. J., and Kuter, G. A. 1987. Interactions between bacteria and Trichoderma hamatum in suppression 
of Rhizoctonia damping-off in bark compost media. Phytopathology 77:1206-1212.

21. Mandelbaum, R., and Hadar, Y. 1990. Effects of available carbon source on microbial activity and suppression of Pythium aphanidermatum in compost and peat container media. Phytopathology 80:794-804.

22. McBeath, J. H., and Kirk, W. W. 2000. Control of seed-borne late blight on pre-cut potato seed with Trichoderma atroviride. Pages 88-97 in: Proceedings of Biocontrol in a New Millennium: Building for the Future on Past Experience. D. M. Huber, ed. Purdue University Press, West Lafayette, IN.

23. Nelson, E. B., Kuter, G. A., and Hoitink, H. A. J. 1983. Effects of fungal antagonists and compost age on suppression of Rhizoctonia damping-off in container media amended with composted hardwood bark. Phytopathology 73:1457-1462.

24. Phae, C. G., Saski, M., Shoda, M., and Kubota, H. 1990. Characteristics of Bacillus subtilis isolated from composts suppressing phytopathogenic microorganisms. Soil Sci. Plant Nutr. 36:575-586.

25. Pharand, B., Carisse, O., and Benhamou, N. 2002. Cytological aspects of compost-mediated induced resistance against Fusarium crown and root rot in tomato. Phytopathology 92:424-438.

26. Pieterse, C. M. J., van Pelt, J. A., Verhagen, B. W. M., Ton, J., van Wees, S. C. M., Leon-Kloosterziel, K. M., and van Loon, L. C. 2003. Induced systemic resistance by plant growth-promoting rhizobacteria. Symbiosis 35:39-54

27. Ristaino, J. B., Madritch, M., Trout, C. L., and Parra, G. 1998. PCR amplification of ribosomal DNA for species identification in the plant pathogen genus Phytophthora. Appl. Environ. Microbiol. 64:948-954.

28. Shaw, D. A., and Madden, L. V. 2004. Nonparametric analysis of ordinal data in designed factorial experiments. Phytopathology 94:33-43.

29. Spencer, S., and Benson, D. M. 1982. Pine bark, hardwood bark compost, and peat amendment effects on development of Phytophthora spp. and lupine root rot. Phytopathology 72:346-351.

30. Sid Ahmed, A., Pèrez Sánchez, C., and Candela, M. E. 2000. Evaluation of induction of systemic resistance in pepper plants (Capsicum annuum) to Phytophthora capsici using Trichoderma harzianum and its relation with capsidiol accumulation. Eur. J. Plant Pathol. 106:817-824.

31. Stone, A. G., Scheurell, S. J., and Darby, H. M. 2004. Suppression of soilborne diseases in field agricultural systems: Organic matter management, cover cropping and other cultural practices. Pages 131-177 in: Soil Organic Matter in Sustainable Agriculture. F. Magdoff and R. R. Weil, eds. CRC Press LLC, Boca Raton, FL.

32. Tuitert, G., Szcech, M., and Bollen, G. J. 1998. Suppression of Rhizoctonia solani in potting mixes amended with compost made from organic household waste. Phytopathology 88:764-773.

33. van Os, G. J., and Van Ginkel, J. H. 2001. Suppression of Pythium root rot in bulbous iris in relation to biomass and activity of the soil microflora. Soil Biol. Biochem. 33:1447-1454.

34. Yedidia, I., Benhamou, N., and Chet, I. 1999. Induction of defense in cucumber plants (Cucumis sativus L.) by the biocontrol agent Trichoderma harzianum. Appl. Environ. Microbiol. 65:1061-1070.

35. Zhang, W., Dick, W. A., and Hoitink, H. A. J. 1996. Compost-induced systemic acquired resistance in cucumber to Pythium root rot and anthracnose. Phytopathology 86:1066-1070.

36. Zhang, W., Han, D. Y., Dick, W. A., Davis, K. R., and Hoitink, H. A. J. 1998. Compost and compost water extract-induced systemic acquired resistance in cucumber and Arabidopsis. Phytopathology 88:450-455. 